\title{
Introduction: A Tropical Lens
}

There is a special charm to journeys undertaken before daybreak in hot lands: the air is soft and cool and the coming of dawn reveals a landscape fresh from the night dew. Aung San Suu Kyi, Letters from Burma (1995-1996)

The landscape of the tropics is being viewed from a fresh tropical lens. This year, the United Nations declared 29 June the 'International Day of the Tropics' - a day dedicated to celebrating and raising awareness of the tropical regions of the world. The date is the anniversary of the launch of the inaugural State of the Tropics 2014 report by Nobel Laureate Aung San Suu Kyi, the first major output of the State of the Tropics project which draws on the expertise of leading tropical institutions from around the world. The 'International Day of the Tropics' testifies to the growing awareness of the significance of the tropics for the entire globe.

This global dynamic calls for new engagements with and within the tropics. In the past, the tropics has been largely defined by the views of outsiders as the region captured the imagination of ancient philosophers and colonial explorers, of artists and scientists. During the inauguration for the 'International Day of the Tropics', a 'tropics lens' for assessing how knowledge and ideas benefitting the tropical region was proposed. This new lens requires the views of creative and innovative scholars: of critical and indigenous thinkers, explorers of the imagination, new media artists, of social scientists and colleagues in cognate disciplines.

Since its inception in 2002, eTropic has continued to publish on issues about the tropics from this humanities, arts and social science lens. This year, as the declaration for an International Day of the Tropics indicates the beginning of a world focus towards the tropics, the journal also has undergone a renewed focus. At the beginning of this year, the Founding Editor initiated the handover of the journal to a new Editor in Chief who has brought together a reinvigorated Editorial Board and an extensive International Editorial Board representing scholars with a diverse range of expertise on, and from, the tropics. The journal now also features a section on Literary and Creative Works managed by a duo of special section Editors. This considerably enlarged ensemble is orchestrated through the dedicated work of our two Editorial Assistants.

This issue is the first under this new editorship and it includes contributions from tropical Australia, Madagascar, Africa, Costa Rica, Brazil, America, Brunei Darussalam, and Singapore. Likewise, the societies and places that form the focus of the tropical lens of each paper gives a sense of the diversity of the tropical belt that girds the world. Beginning from the broad lens of the Tropics worldwide, papers then home in to the regions of Sao Paulo in Brazil, Zimbabwe in Africa, Northern Queensland in Australia, Fiji and the South Pacific, Brunei and Sarawak on the island of Borneo, Southeast Asia, and further across tropical Asia. 
The first paper sets the scene for this special issue on the International Day of the Tropics with voices from representatives present at the United Nations on that inaugural International Day of the Tropics. Her Excellency Gillian Bird, the Australian Permanent Representative and Ambassador to the United Nations, reminds us that tropical challenges require tropical solutions. This point is demonstrated with quoted examples from His Excellency Ahmed Sareer, Ambassador and Permanent Representative of the Maldives, and His Excellency Peter Thomson, President of the United Nations General Assembly and former Permanent Representative and Ambassador of Fiji. Several academic experts joined the voices of these diplomats. Elizabeth Losos, the President and CEO of the Organisation for Tropical Studies located in Costa Rica, spoke on the diversity, connectivity and dynamism of ecosystems, especially those of the Amazon rainforests of Ecuador. Rose Aderolili, chief economist of Otino International, spoke of the potential of a young and dynamic Africa with an example from Uganda. Peter Hotez, Dean of the National School of Tropical Medicine at Baylor College of Medicine in the USA, explained the rise in tropical diseases and the necessity of multidisciplinary research. Sandra Harding, Vice Chancellor and President of James Cook University Australia and Singapore, gave an overview of major findings from the State of the Tropics project: from demographics to health, to linguistic and cultural diversity, to ecosystems and climate change. The conclusion is that multidisciplinary research - which arises from and with tropical scholars - is necessary in order to address the unique knowledge needs of the tropics.

The question of the need for unique knowledges, arising from the tropics, in order to address the issues of the tropics, is at the heart of the paper by Luisa Amador Fanaro who studies the human-animal relations of the remaining African-Brazilian Quilombolo communities of the state of São Paulo in Brazil. The interrelations between animals and humans forms a distinct field in anthropology, science and technology studies, the humanities and arts. Fanaro seeks the viewpoints of Quilombolo communities in order to understand how human-animal relations also underlie their notions of territoriality. Her hope is that such case studies can assist in the processes of land claims and the recognition of Quilombolo territories within the state of Brazil.

The paper by Richard Gehrmann and Rachel Hammersley-Mather begins up the Limpopo River in tropical Africa. Their paper explores voyage and migration through Lauren St John's Rainbow's End, a female coming of age memoir that chronicles the author's experiences of 1970s Rhodesia and her growing awareness of white privilege and racial inequalities as the country transforms into Zimbabwe. The paper also tells the stories of other voyages of Rainbow's End - of a father's masculine journey to fight in the Rhodesian war, and a mother's travels to exotic Europe to escape the mundane world of marriage, farm life and gossip in a narrow-minded semi-colonial tropical rural environment. The paper aims to contribute to literary analysis of colonial history in the African tropics, and it reminds us of the inextricable relationship between place and identity.

Movement in the tropics is also taken up in Jacqueline Scotcher's paper on wayfaring and creative art practice in tropical Far North Queensland, Australia. The author demonstrates how 
walking in nature, is an immersive practice that enables the artist to form deep connections with the environment which, stimulates the artistic imagination beyond mere outsider representations of landscape. The importance of practices of wandering and wondering are demonstrated throughout the author's text in both words and through images created from the embodied experiences of the specific natural environments of tropical north Queensland.

The impact of tropical nature on human experience and imagination is also the lens of Chrystopher Spicer's paper. In this case, the climatic element of the tropical storm is explored through literature as the author argues that weather impacts people's life experiences. The tropical storm - including, tornadoes, hurricanes and cyclones - is a recurring trope in literature from classical texts, to seafaring adventure yarns, to poetry. Although this literature has been well documented for other parts of the world, Spicer's research is to analyse the presence of the tropical cyclone in the literary imagination of Queensland and its effect on local knowledges as they are expressed in a variety of texts.

The paper by Marie M'Balla-Ndi and Maxine Newton, critiques parachute journalism in the South Pacific with its emphasis on torrid zones tropes of tropical natural disasters and military coups. They argue for a more ethical and respectful practice embedded in journalism education that includes the social and cultural understanding of the peoples of the tropical Pacific. Their paper outlines Habermas's theory of communicative action, and the indigenous South Pacific communicative practice of talanoa. The authors conclude that innovative journalism needs to take into account not only relevant western theories regarding communication, but also local communicative practices. Their paper supports the call for an indigenous tropical lens to counter one-sided western perspectives.

Local forms of communication and engagement are also highlighted in the paper by Janet Marles, Maslin Bin Haji Jukim, and Frank Dhont who present work from an oral history archive that examines local memories of the World War II Japanese occupation of the island of Borneo in Southeast Asia. The authors argue that oral accounts add specificity and depth to historical narratives. Furthermore, in this study where graduate students from Sarawak, Malaysia, and Brunei Darussalam, were engaged in the video recordings for the oral history archive, it also aids to connect Borneo youth with their elders. The richness of the archive is its ability to record history as told through multiple individual lenses, articulated in numerous local languages. This paper demonstrates the significance of local knowledges to understanding the diversity of the tropics.

Yvette Yanwen Lim's paper moves us to contemporary Southeast Asia as she investigates queer spaces in relation to urbanism, bodies and sexuality as they are evoked in film. Through an analysis of films from the Philippines, Thailand and Singapore, she argues that urbanization in Southeast Asia, despite indicators measuring progress, continues to perpetuate heteronormativity and patriarchy and that progress towards diversity and inclusivity remains fraught with challenges. Her paper serves to reminds us that the tropics is a space of massive economic growth and rapid urbanization - but it also faces pressing contemporary issues regarding equality and diversity. 
In the last paper in this issue, Anita Lundberg, turns us to the issues of women, poverty and power, examining the possibility of empowerment for women through networks. She argues that the tropics - even as it experiences growth - also remains a region which bears a burden of world poverty, and that women and girls continue to bare the unequal share of this poverty. Females also remain disempowered, and their voices continue to strive to be heard. The paper outlines networks across multiple plateaux that draw on examples from across tropical Asia. Beginning with a visual analysis of the networks evoked through an art piece, the paper rides on transportation networks, engages a women's philanthropic network, outlines women's microfinance networks, and finally argues for the importance of education and alumni networks for empowering women of the tropics for the future of all genders.

Together this collection of scholarly papers offers a wide range of approaches from the humanities, arts, social sciences and cognate fields that demonstrate how these disciplines engage - creatively, innovatively, imaginatively, theoretically and practically - with diverse regions of the tropics. These papers address the United Nations International Day of the Tropics by articulating what that day may mean from various lenses. What they have in common is that each paper calls for a better future for people and societies of the tropics worldwide.

Returning to the beginning of this introduction for this special issue, we once again encounter the quotation of Aung San Suu Kyi. The quotation reminds us of the charm of journeys undertaken before daybreak in our tropical lands. Indeed, if we take these words metaphorically, they suggest how a softer air may reveal fresh landscapes to our lens. Such has always been the need for the views offered by the humanities, arts and social sciences. This soft lens is crucial if we are to awaken a new dawn for the tropics.

Anita Lundberg

Editor in Chief, eTropic James Cook University Singapore 